\title{
Evaluation of a New Tablet Formulation Based on Bacillus thuringiensis sorovar. israelensis for Larvicidal Control of Aedes aegypti
}

\author{
Maria Alice Varjal de Melo-Santos/ ${ }^{+}$, Elizabeth Gomes Sanches*, \\ Fernando Justino de Jesus*, Lêda Regis
}

\author{
Departamento de Entomologia, Centro de Pesquisas Aggeu Magalhães-Fiocruz, Caixa Postal 4742, 50670-420 \\ Recife, PE, Brasil *Far-Manguinhos-Fiocruz, Rio de Janeiro, RJ, Brasil
}

The effect of sunlight on the efficacy and persistence of an experimental tablet formulation based on Bacillus thuringiensis sorovar. israelensis (C4P1) was evaluated against Aedes aegypti larvae under simulated field conditions. The initial mortality ranged from 93 to $100 \%$, and the residual activity $\geq$ 70\% mortality) recorded in containers exposed to sunlight or shade were, respectively, 13-35 days and 40-54 days. The results suggest that C4P1 can provide long-term larvicidal effect and operational advantages.

Key words: Bacillus thuringiensis israelensis - Aedes aegypti - tablet formulation

Bacillus thuringiensis sorovar. israelensis (B.t.i) has been used since the 80's in several programs for controlling black fly and mosquito species worldwide. It is considered highly toxic to the target organisms and environmentally safe. Furthermore, no resistance has been detected on populations submitted to long-term exposure to this pathogen (Regis \& Nielsen-LeRoux 2000). B.t.i formulations have been continuously improved to optimise their potency, stability (shelf life), ease of field application and residual activity (Couch 2000). Trials under simulated field conditions have been considered a reliable methodology to evaluate the efficacy and persistence of B.t.i based products because, under these conditions, many factors involved in residual activity can be better controlled and investigated than under real field conditions (Thiéry et al. 1999, Regis et al. 2000).

In the present work, the effect of sunlight on the efficacy and residual activity of a new tablet formulation based on B.t.i, C4P1 against Aedes

\footnotetext{
This work is part of MAV Melo-Santos Master Program in Animal Biology and was sponsored by CNPq, Capes/Facepe.

${ }^{+}$Corresponding author. Fax: +55-81-3453.2449. E-mail: mavarjal@cpqam.fiocruz.br

Received 25 January 2001

Accepted 25 April 2001
}

aegypti larvae (Recife-Lab strain), was investigated under simulated field conditions. C4P1 is an experimental slow release solid formulation, developed by Far-Manguinhos-Fiocruz, Rio de Janeiro, Brazil. Initially, the larvicidal activity of the technical powder was determined by bioassay according to the standard protocol (de Barjac \& LargetThiéry 1984). The $\mathrm{LC}_{50}$ and the $\mathrm{LC}_{90}$ were titrated against the B.t.i reference powder (IPS82), from Institut Pasteur. The technical powder showed $\mathrm{LC}_{50}$ $=0.30 \pm 0.01 \mathrm{mg} / \mathrm{l}$ and $\mathrm{LC}_{90}=0.44 \pm 0.01 \mathrm{mg} / \mathrm{l}$, resulting in potency of $1,146 \pm 52 \mathrm{ITU} / \mathrm{mg}$ (International Toxic Units).

The tests under simulated conditions were carried out in March (1st set) and May (2nd set) 2000 to evaluate the residual activity of $\mathrm{C} 4 \mathrm{P} 1$ related to the incidence of sunlight. The containers, placed in an outdoor area, were submitted to direct sunlight and shade. The tests were conducted in plastic containers $(38 \times 42 \times 30 \mathrm{~cm})$ filled with 201 of tap water where the temperature ranged from 27 to $29^{\circ} \mathrm{C}$ in the shade and from 27 to $32^{\circ} \mathrm{C}$, in direct sunlight. Each container was treated with 1 tablet/ 101 . Fifty early fourth-instar larvae (L4) were introduced into each container and the mortality rate was recorded $48 \mathrm{~h}$ after, by counting the surviving larvae. This procedure was always used to determine the initial mortality. Thereafter, the evaluation of residual activity was carried out using 50 L4 or 300 first instar (L1) larvae per container. L4 or L1 were introduced, respectively, at every 3 or 5 days, and the larval mortality was recorded be- 
fore introducing each new batch of larvae. Containers were observed until the moment that larval mortality recorded was $\geq 70 \%$. In all experiments C4P1 was tested in triplicate for each condition and two untreated containers were left as controls. The results were compared using Mann Whitney test.

The results obtained showed that the mean initial mortality achieved was $100 \%$ in the 1 st set of experiments and 93 to $100 \%$ in the 2nd one. The residual activity was clearly affected by sunlight radiation, resulting in significant reduction in the persistence period, when compared with the tests in shade (Table). Under both conditions, the best persistence was recorded in the experiments carried out in May when the dose applied was able to kill more than $90 \%$ of the larvae during 35 days in containers exposed to sunlight and more than 50 days in shaded containers. Those results suggest that $\mathrm{C} 4 \mathrm{P} 1$ is a good formulation, releasing the active ingredient slowly in the mosquito feeding zone over a long time. In recent reports tablet formulations have been considered more highly suited to control A. aegypti than other formulations (Becker 2000).

The experiments using L1 larvae were more sensitive to detect the residual activity than those using L4. Indeed, the persistence period recorded

\section{TABLE}

Persistence of the Bacillus thuringiensis sorovar. israelensis tablet $\mathrm{C} 4 \mathrm{P} 1$ recorded in tests under outdoor simulated conditions against Aedes aegypti larvae (Recife-Lab strain)

\begin{tabular}{|c|c|c|}
\hline $\begin{array}{l}\text { Experimental } \\
\text { condition }\end{array}$ & $\begin{array}{l}\text { Larval } \\
\text { instar }\end{array}$ & $\begin{array}{c}\text { Persistence (days) } \\
(\text { Mean } \pm \text { SD })\end{array}$ \\
\hline \multicolumn{3}{|l|}{ 1st set (March 2000) } \\
\hline Sun & L4 & $13.0 \pm 1.7$ \\
\hline Shade & L4 & $40.3 \pm 1.5$ \\
\hline Sun & L1 & $25.0 \pm 0.0$ \\
\hline \multicolumn{3}{|l|}{ 2nd set (May 2000) } \\
\hline Sun & L1 & $35.3 \pm 4.6$ \\
\hline Shade & L1 & $54.0 \pm 0.0$ \\
\hline
\end{tabular}

L4: early fourth-instar larvae; L1: first-instar larvae; $a$ : the persistence correspond to the period (in days) when more than $70 \%$ mortality was recorded in the containers. The persistence were significantly different $(\mathrm{P}<0.05)$ in all cases. in the experiments using L1 was two times longer in the containers exposed to sunlight (Table). Although laborious, the tests using $\mathrm{L} 1$ are more representative of field situations.

In summary, this trial demonstrated that the C4P1 tablet has provided control of A. aegypti larvae lasting for 40-54 days under shade conditions and giving acceptable control under sunny conditions, lasting for 13-35 days, after a single treatment. In addition to the safety of B.t.i to the environment, the tablet $\mathrm{C} 4 \mathrm{P} 1$ has the advantage of being of easy application, especially in small water containers and it can be an useful tool for A. aegypti control in urban areas.

\section{ACKNOWLEDGEMENTS}

To Dr Maria Helena NL Silva Filha for critical reading of manuscript and helpful comments, and Drs Wayner de Souza and Ulisses Montarroyos for statistical support. To Institut Pasteur for providing the B.t.i reference powder IPS82.

\section{REFERENCES}

Becker N 2000. Bacterial control of vector-mosquitoes and black flies. In JF Charles, A Delécluse, C Nielsen-LeRoux (eds), Entomopathogenic Bacteria: from Laboratory to Field Application, Kluwer Academic Publishers, Dordrecht, p. 383-396.

Couch TL 2000. Industrial fermentation and formulation of entomopathogenic bacteria. In JF Charles, A Delécluse, C Nielsen-LeRoux (eds), Entomopathogenic Bacteria: from Laboratory to Field Application, Kluwer Academic Publishers, Dordrecht, p. 297-314.

de Barjac H, Larget-Thiéry I 1984. Characteristics of IPS82 as standard for biological assay of Bacillus thuringiensis $\mathrm{H}-14$ preparations. Mimeographed document WHO/VBC/84.892. World Health Organization, Geneva.

Regis L, Nielsen-LeRoux C 2000. Management of resistance to bacterial vector control. In JF Charles, A Delécluse, C Nielsen-LeRoux (eds), Entomopathogenic Bacteria: from Laboratory to Field Application, Kluwer Academic Publishers, Dordrecht, p. 419-441.

Regis L, Silva SB, Melo-Santos MA 2000. The use of bacterial larvicides in mosquito and black fly control programmes in Brazil. Mem Inst Oswaldo Cruz 95: 207-210.

Thiéry I, Fouque F, Gaven B, Lagneau C 1999. Residual activity of Bacillus thuringiensis serovars medellin and jegathesan on Culex pipiens and Aedes aegypti larvae. J Am Mosq Control Assoc 15: 371-379. 